\title{
A Decade of Charter Schools: From Theory to Practice
}

Katrina Bulkley

Jennifer Fisher

Follow this and additional works at: https://repository.upenn.edu/cpre_policybriefs

Part of the Curriculum and Instruction Commons, Educational Leadership Commons, Educational Methods Commons, Education Policy Commons, and the Other Education Commons

\section{Recommended Citation}

Bulkley, Katrina and Fisher, Jennifer. (2002). A Decade of Charter Schools: From Theory to Practice. CPRE Policy Briefs.

Retrieved from https://repository.upenn.edu/cpre_policybriefs/23

View on the CPRE website.

This paper is posted at ScholarlyCommons. https://repository.upenn.edu/cpre_policybriefs/23

For more information, please contact repository@pobox.upenn.edu. 


\title{
A Decade of Charter Schools: From Theory to Practice
}

\author{
Abstract \\ The number of schools operating under charter school laws has soared over the last decade, from a small \\ number operating in just a few states to more than 2,300 schools serving over 575,000 students in 34 \\ states and the District of Columbia. More than half of these schools are concentrated in a few states - \\ Arizona has over 400 charter schools, and California, Florida, Michigan, and Texas each has more than \\ 150. \\ Charter schools are relatively autonomous schools of choice that operate under a charter or contract \\ issued by a public entity such as a local school board, public university, or state board of education. In \\ theory, these contracts, usually lasting three-to-five years, provide school operators more autonomy than \\ afforded a district-run public school in exchange for enhanced accountability by requiring schools to \\ prove they are worthy of succeeding contracts. \\ The Consortium for Policy Research in Education (CPRE) was commissioned by the U.S. Department of \\ Education to conduct a review of the research on charter schools. This CPRE Policy Brief summarizes \\ some key findings of our review. \\ It is important to note that charter schools are an institutional innovation, meaning the laws allow schools \\ to operate under a different structure. Charter school laws are not an attempt to endorse any particular \\ learning approach or curriculum in the schools. Ted Kolderie, one of the creators of the charter school \\ concept, explains that, "...the chartered school is not a kind of school; not a A Decade of Charter Schools: \\ From Theory to Practice By Katrina Bulkley and Jennifer Fisler learning program or method. The \\ opportunity the law provides is an empty institutional structure, as a building is an empty physical \\ structure. Students learn from what the organizers put into it" (personal communication, October 25, \\ 2001). Thus, in comparing schools operating under charter school laws with those directly operated by \\ public school districts, it is necessary to consider the substantial variation under the charter school \\ umbrella. \\ Disciplines \\ Curriculum and Instruction | Educational Leadership | Educational Methods | Education Policy | Other \\ Education \\ Comments \\ View on the CPRE website.
}




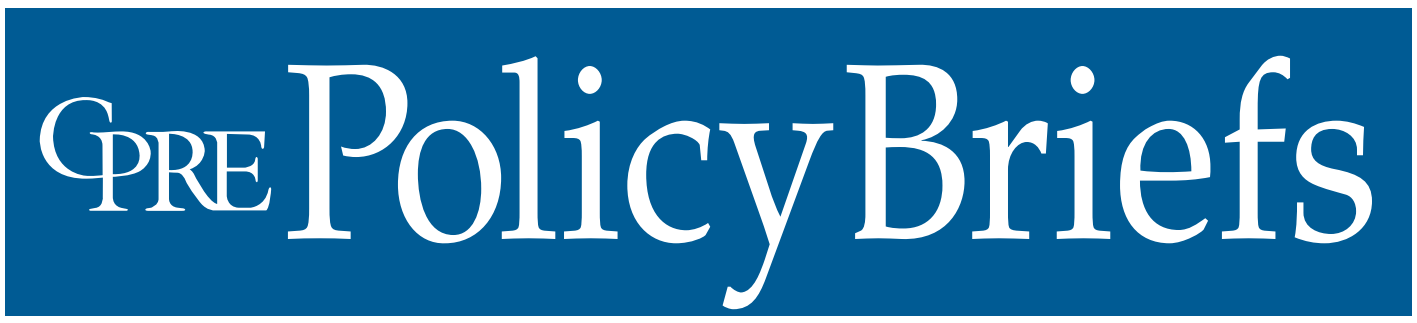

Reporting on Issues and Research in Education Policy and Finance
April 2002

RB-35

Graduate School

of Education

University of

Pennsylvania

\section{A Decade of Charter Schools: From Theory to Practice}

\section{By Katrina Bulkley and Jennifer Fisler}

The number of schools operating under charter school laws has soared over the last decade, from a small number operating in just a few states to more than 2,300 schools serving over 575,000 students in 34 states and the District of Columbia. More than half of these schools are concentrated in a few states - Arizona has over 400 charter schools, and California, Florida, Michigan, and Texas each has more than $150 .{ }^{1}$

Charter schools are relatively autonomous schools of choice that operate under a charter or contract issued by a public entity such as a local school board, public university, or state board of education. In theory, these contracts, usually lasting three-to-five years, provide school operators more autonomy than afforded a district-run public school in exchange for enhanced accountability by requiring schools to prove they are worthy of succeeding contracts.

The Consortium for Policy Research in Education (CPRE) was commissioned by the U.S. Department of Education to conduct a review of the research on charter schools. This CPRE Policy Brief summarizes some key findings of our review. ${ }^{2}$

It is important to note that charter schools are an institutional innovation, meaning the laws allow schools to operate under a different structure. Charter school laws are not an attempt to endorse any particular learning approach or curriculum in the schools. Ted Kolderie, one of the creators of the charter school concept, explains that, "...the chartered school is not a kind of school; not a learning program or method. The opportunity the law provides is an empty institutional structure, as a building is an empty physical structure. Students learn from what the organizers put into it" (personal communication, October 25, 2001). ${ }^{3}$ Thus, in comparing schools operating under charter school laws with those directly operated by public school districts, it is necessary to consider the substantial variation under the charter school umbrella.

Early proponents of charter schools predicted five beneficial outcomes:

- Adoption of charter school laws would lead to the creation of new or reinvention of existing schools (public and/or private, depending on the state law), thereby expanding both the number and variety of public school choices available to parents (Kolderie, 1990; Nathan, 1996).

- Charter schools would have more autonomy and flexibility than district-operated public schools by virtue of their independence from school districts, waivers from state laws and regulations, and student/parent choice (Wohlstetter, Wenning, \& Briggs, 1995).

- The interplay of autonomy and market forces would make charter schools more innovative and of higher quality than district-run public schools in areas of instruction and curriculum, school organization and governance, and in some cases, alter teacher qualifications and union involvement (Arsen, Plank, \& Sykes, 1999).

\section{Consortium for Policy Research in Education}

University of Pennsylvania

Harvard University

Stanford University

University of Michigan

University of Wisconsin-Madison

\footnotetext{
${ }^{1}$ See the Center for Education Reform web site at http://www.edreform.com.

${ }^{2}$ A more expanded version of the review is available at http://www.cpre.org.

${ }^{3}$ Kolderie (1998) makes a similar argument in an article for the Charter Friends Network.
} 
- Charter schools would be more accountable than district-run schools because they would have to meet demands of parent and student consumers and of short-term performance contracts with government agencies that provide public funding (Kolderie, 1990).

- The combination of autonomy, innovation, and accountability would lead to improved student achievement, high parental and student satisfaction, high teacher/employee satisfaction and empowerment, positive effects on the broader system of public education, and positive or neutral effects on educational equity, including better services for at-risk students (Nathan, 1996).

The growing research literature on charter schools, although not always easy to interpret (especially because of important state-to-state variations), begins to answer some basic questions about whether charter schools are living up to their promise. ${ }^{4}$ This CPRE Policy Brief covers the major research areas of the last decade, which largely focused on comparing the implementation of charter schools with the original concept. This review provides a foundation for future work that will examine in greater depth the role charter schools may play in educational reform.

\section{Charter School Demographics}

\section{Do Charter Schools Differ Demograph- ically from Traditional Public Schools?}

Charter schools tend to be much smaller than district-operated schools; charter schools have a median enrollment of $137 \mathrm{stu}-$ dents in comparison to the 475-student enrollment of district schools (RPP International, 2000). Charter schools nationwide have student demographics similar to other public schools. According to the RPP International study (2000), charter schools nationally enrolled approximately $11 \%$ fewer White students, 7\% more African American students, $3 \%$ more Hispanic students, slightly higher percentages of students eligible for free or reduced-price lunch, and about the same percentage of students having limited-Englishproficiency as regular public schools. Student and school characteristics, however, vary considerably across the country, with charter
CPRE is funded by the National Institute on Educational Governance, Finance, Policymaking, and Management; Office of Educational Research and Improvement; U.S. Department of Education. The research reported in this brief was conducted by CPRE and funded under OERI Grant No. R308A960003. Opinions expressed in this brief are those of the authors and do not necessarily reflect the views of the National Institute on Educational Governance, Finance, Policymaking, and Management; the Office of Educational Research and Improvement; the U.S. Department of Education; Rutgers University; $C P R E$; or its institutional members.

schools in some states far more likely to serve urban and at-risk students (RPP International, 1999). There is evidence in at least some states that charter schools are more likely to be located in urban areas (Arsen et al., 1999).

\section{Autonomy}

\section{Are Charter Schools Truly Autonomous?}

It is hard to generalize about the autonomy of charter schools because autonomy has a variety of meanings and because there is so much variation across states. Autonomy can mean freedom from state regulation, autonomy with respect to a district or chartering agency (including control over budget, personnel decisions, curriculum, and instruction), and autonomy for parents and students through school choice (Wohlstetter et al., 1995).

Half of the states with charter school laws allow charter schools to waive many state laws, rules, and regulations. Waivers are uncommon for such areas as fiscal requirements and student assessment policies, but more common in collective bargaining and teacher certification (SRI International, 2000). In Colorado, where schools can request waivers from specific state requirements, charter school personnel told researchers that their highest priorities were waivers related to site control of curriculum and employment/personnel issues (Clayton Foundation, 1999).

One four-state study concluded that politics affected how much autonomy individual schools had from state requirements. Hassel (1999) found that, when the political climate was generally supportive of charters, schools had similar experiences even though their states had varying amounts of deregulation.

${ }^{4}$ For this policy brief, we reviewed over 50 studies on charter schools. This brief focuses on a subset of the literature - state evaluations, federally-funded studies that are national in scope, and other research that has received substantial attention in the charter school research community or is of particular relevance to the topics covered here. 
A recent national study found that most charter schools had primary control over purchasing, hiring, scheduling, and curriculum, while slightly fewer charter schools controlled student assessment and their budgets (RPP International, 2000; see also Wells, 1998; WestEd \& University of Southern California, 1998). ${ }^{5}$ State governments face a continuing tension between ensuring that charter schools operate in ways consistent with the broad public interest and not recreating the existing bureaucratic system.

Several factors that influence charter school autonomy have been identified. Charter schools with authorizers other than local school districts tend to have more autonomy (SRI International, 2000; Wells, 1998). Charter schools that were formerly public schools tend to have less control "in all areas of decision making and policy-setting" (RPP International, 2000). In recent years, some states have acted to increase autonomy by expanding the types of agencies eligible to grant charters. The thinking behind these changes is that different agencies might allow different types and levels of autonomy (SRI International, 2000). The involvement of educational management organizations has also been found to influence the amount of autonomy available to charter schools (Bulkley, 2001).

In sum, evidence is strong that charter schools are more autonomous than districtoperated public schools, although the level of autonomy varies considerably.

\section{Is More Charter School Autonomy Always a Good Thing?}

Charter school advocates have generally considered more autonomy to be better (see Kolderie, 1990), but the research to date is not clear. One study found that schools operating with greater autonomy were better able to create and sustain learning communities and respond quickly to problems, but were more consumed by managerial decisions (Wohlstetter \& Griffin, 1998). Another study suggested that, despite their desire for autonomy, charter schools often turned to their local district's bureaucracy when they needed help (Wells, 1998). Some schools, particularly those with weak organizational structures, may have difficulty capitalizing on their autonomy (Wohlstetter \& Griffin, 1998).
Autonomy does not imply that charter schools should be left to fend for themselves. Charter schools can obtain valuable assistance from supportive authorizing agencies, state charter school organizations, and private entities that assist individual schools (such as the Charter School Resource Center operated by the Pioneer Institute in Massachusetts) (Hill et al., 2001). A study of New York charter schools found that most charter school administrators "sought to strengthen their schools through a mix of autonomy and connection" (Ascher, Jacobowitz, McBride, \& Wamba, 2000, p. 18). Another study suggested that management companies like National Heritage Academies and the Edison Project tend to "fill the gap for the charter schools that in the traditional public school system is filled by the school district office" (Mintrom, 2000, p. 26).

\section{Innovation}

\section{Are Charter Schools Governed and Managed Differently?}

Arsen et al. (1999) see control over school governance as the most important innovation of charter schools, which is consistent with an institutional innovation. The governance of charter schools is diverse, including schools that are dominated by teachers, by administrators, and by parents. School leaders are also important, as they are in district-run public schools (Wells, 1998; WestEd \& University of Southern California, 1998), but charter school leaders come from more varied backgrounds than those in district school systems.

The use of for-profit or non-profit educational management organizations (EMOs), also called Educational Service Providers, is a management innovation found more frequently in charter schools than in traditional public schools. These organizations provide a variety of services, ranging from accounting or hiring services to operating every aspect of the schools. The practice is far more prevalent in some states than others. For example, 70\% of charter schools in Michigan contract with EMOs (Arsen et al., 1999). A reduced influence of teacher unions is another management change found among charter schools. A 1998 study funded by the National Education Association found that $68 \%$ of charter school

${ }^{5}$ In most states, charter schools that have more applicants than seats accept students through a lottery process. 
teachers reported little or no union involvement in their schools (Koppich, Holmes, \& Plecki, 1998).

\section{Are Charter Schools Organized Differently than Public Schools?}

Innovations in school organization involve school and class sizes, grade configurations, staffing patterns, and use of staff time (Arsen et al., 1999). Charter schools tend to be much smaller than district-run public schools, and almost half have grade configurations that vary from the traditional elementary, middle, and secondary school patterns (RPP International, 2000). Charter schools are also more likely to innovate in grade placement of students. In Massachusetts, $76 \%$ of the charter schools studied used at least some multi-age groupings (Rosenblum Brigham Associates, 1998).

\section{How Do Charter School Teachers Differ from Teachers in District-run Public Schools?}

Charter school teachers are less likely to be certified than their peers in district-operated public schools (RPP International, 1999). Certification rates of charter school teachers, however, vary by state, from $100 \%$ in Kansas and Rhode Island to $49 \%$ in Illinois (RPP International, 1999). A recent Texas study found that slightly more than half of their charter school teachers were certified (Texas Education Agency, 2000). The same Texas study found that teachers in non-at-risk schools were more likely to be certified $(52.5 \%)$ or working toward certification than those teaching in at-risk schools (37.7\%). There is evidence in some states that charter school teachers have less teaching experience than their public school peers (see Center for Applied Research and Educational Improvement, 1998).

\section{Are Charter Schools Fostering Innovation in the Classroom?}

We know far less about what happens inside charter school classrooms than we know about how charter schools are organized and governed. The definition of "innovation" in itself is not clear: some argue that it refers to something altogether new, while others see it as something new to a particular context (for example, a "back-to-basics cur- riculum," small size, or a clearly focused mission). One study noted that innovation "does not always mean plowing virgin soil" (Finn, Manno, \& Vanourek, 2000, p. 91).

Little charter school research has looked broadly at the pedagogy in charter schools. A 1997 study of California charter schools found that charters used a mix of traditional classroom-based instruction and other methods such as home-based instruction and independent study (SRI International, 1997). A Massachusetts study found that many charter schools had a strong "unifying focus," perhaps related to content (performing arts, for example) or a general approach to education (such as a democratic community) (Rosenblum Brigham Associates, 1998). A Michigan study concluded that charter schools were somewhat more likely to engage in curricular innovations (including back-to-basics approaches) than other public schools, but were often "essentially working to create localized variations of practices that are already common within the broader public school community" (Mintrom, 2000, p. 29). Some of the most innovative practices in Michigan were taking place in charter schools, Mintrom noted, but many charter schools were not engaging in what respondents described as new practices. Key factors in making some Michigan charter schools more innovative than others were motivation, lack of constraints, and an inclusive deliberative process within the school.

Broad findings about practices within schools would be difficult to make (even if there were more school-level research), given the institutional nature of charter school reform. Indeed, generalized statements about charter school instruction would be somewhat contrary to a reform meant to allow for a wide range of curricular and pedagogical approaches.

\section{Accountability to Government and the Market}

\section{How Do States Ensure that Charter Schools are Accountable?}

Every chartering agency responding to a recent survey reported that some or all of its schools have measurable goals in the area of student achievement (SRI International, 2000). A number of studies suggest that over- 
sight is often focused more on compliance and financial stability than on student performance (Bulkley, 1999; Henig, Moser, Holyoke, \& Lacireno-Paquet, 1999; Hill et al., 2001; SRI International, 1997). In a survey conducted by SRI International (2000), chartering agencies reported that they focused on curriculum, finances, and assessment during the chartergranting process and, once schools were operating, focused on student achievement, financial record-keeping, and compliance with federal and state regulations. Despite strong rhetoric about closing schools as a critical means of promoting accountability, the charter schools that have been closed by authorizing agencies have suffered primarily from managerial and fiscal problems, not inadequate student achievement. This is consistent with evidence that chartering agencies are struggling to implement performance-based accountability (Bulkley, 2001). Some states and other chartering agencies are exploring other approaches to assess and hold schools accountable for educational quality. The recent report by SRI International (2000) discussed different "corrective actions" that have been taken, while another study examined new models of external accountability such as inspectorates in Massachusetts and peer review (Hill et al., 2001).

Charter schools often focus more on internal accountability - accountability to teachers, parents, and students - than on accountability to their chartering agencies (Wohlstetter \& Griffin, 1998). One study observed, "The fact that charter schools must maintain relationships of trust and confidence with parents and teachers, as well as to government, motivates the intense internal collaboration that leads to internal accountability" (Hill et al., 2001, p. iv).

\section{How Do Charter Schools Measure Student Performance, and what are States Doing to Address Unsatisfactory Performance?}

Accountability, especially for student performance, is often cited as a core argument in favor of charter schools (Finn et al., 2000; Nathan, 1996). RPP International surveys (2000) show that $96.4 \%$ of charter schools are using standardized assessments, usually in conjunction with other assessment measures, and reporting this information to their chartering agencies. A national study of charter school accountability concluded that, "Finding ways to measure not only student achievement on standardized tests but the value-added qualities of charter schools has proven to be a challenge [for chartering agencies]" (Hill et al., 2001, p. vi). ${ }^{6}$ In addition, the expectations of chartering agencies can be unclear (see Wohlstetter \& Griffin, 1998, p. 15). Finn and his colleagues (2000) argue that instead of focusing on achievement, charter school accountability, despite good intentions, "typically means a half-baked version of the top-down regulation-and-compliance system that the state or community applies to its conventional public schools" (p. 135).

Revocation or non-renewal of charter contracts is the ultimate instrument of governmental accountability, but roughly two-thirds of the states with charter schools have not yet evaluated their schools for renewal (SRI International, 2000). Almost all charter schools that have closed - whether of their own accord or through revocation or nonrenewal - have closed for reasons unrelated or only indirectly related to educational performance (Center for Education Reform, 2000). The most common reasons for closing have been "organizational chaos, management meltdown, and fiscal shenanigans" (Finn et al., 2000, p. 137).

\section{How Do Parents Rate their Children's Charter Schools?}

Parents generally give their charter schools positive marks. A review of research conducted by RAND found that "...parents of children in voucher and charter schools are more satisfied, on a wide variety of dimensions, than are comparison groups of local public school parents" (Gill, Timpane, Ross, \& Brewer, 2001, p. 137). In Minnesota and Texas, $85-90 \%$ of charter school parents (compared with $70 \%$ of public school parents nationally) gave their schools an " $\mathrm{A}$ " or " $\mathrm{B}$ " (Center for Applied Research and Educational Improvement, 1998; Rose \& Gallup, 2000; Texas Education Agency, 2000). Finn and his

${ }^{6}$ Authorizing legislation in several states (including Texas, Louisiana, and New Hampshire) requires charter schools to demonstrate acceptable levels of performance or improvement, based at least in part on test scores (Lake \& Millot, 1998). It is unclear what effect this requirement will have on charter renewals in these states. 
colleagues (2000) cited survey data (from schools recommended by state personnel) indicating that charters were "extremely popular" among parents, who rated them superior to their children's previous schools with regard to class size, school size, attention from teachers, quality of instruction, and curriculum. Several indicators of market satisfaction (including the common existence of waiting lists) support the conclusion that parents and students are often satisfied with charter schools (see RPP International, 2000).

\section{How Involved are Parents in Charter Schools?}

Parents appear to be highly involved with charter schools. Minnesota parents, for example, reported that they were more involved with their charter school than with previous schools (Center for Applied Research and Educational Improvement, 1998). Another study suggested that active parent involvement can be a mixed blessing: "In some cases, there was such a high degree of parent involvement that clear parameters and boundaries needed to be established to guide interaction" (WestEd \& University of Southern California, 1998, p. 15). Parents have been less involved in some states. In Pennsylvania, where charter schools serve a lower-income student population than the state as a whole, only $25 \%$ of parents reported one form of parental involvement, volunteering more than three hours a month at their children's schools (Miron \& Nelson, 2000).

\section{What are Students' Attitudes about Attending Charter Schools?}

Surveys suggest that students are generally satisfied with the charter schools they attend. In identifying things they disliked, students tended to focus on non-academic matters such as the sports program, activities, and food, as well as complaining that there was too much homework (see Center for Applied Research and Educational Improvement, 1998; Mulholland, 1999). In Connecticut, 61\% of charter students said they would recommend a charter school to a friend, despite having reservations about financial resources and curricular and extracurricular activities (Horn \& Miron, 1998).

\section{How Do Teachers Like Teaching in Charter Schools?}

Charter school teachers typically have high satisfaction ratings. A survey of Minnesota charter school teachers found $81 \%$ to be satisfied or very satisfied and only $6 \%$ dissatisfied or very dissatisfied (Center for Applied Research and Educational Improvement, 1998). These highly positive ratings, it should be noted, were also typical among teachers in district-operated public schools nationally who completed the same survey. Charter school teachers in Connecticut also reported high levels of satisfaction, although the levels diminished after the first year (Horn \& Miron, 1998). California charter school teachers felt positively about their schools, but found teaching there to be an overwhelming experience, which may help explain the high levels of teacher turnover in some charter schools (see also Texas Education Agency, 1999; Wells, 1998).

A sense of teacher empowerment can serve as another measure of teacher satisfaction, but there is more than one locus of empowerment. A Colorado study found that charter school teachers felt more empowered within their classrooms, but less empowered in their schools than teachers in district-run public schools (Bomotti, Ginsberg, \& Cobb, 1999). The charter school teachers were somewhat more satisfied with conditions for teaching and learning, but less satisfied with the physical plant and school support.

\section{Equity}

\section{What Effects are Charter Schools Having on Racial or Ethnic Balance in Schools and Serving Low-income Students?}

A recent national study suggests that, overall, the racial composition of students enrolled in charter schools was similar to that of their local public school districts. Nearly $70 \%$ of charter schools had a student racial and ethnic composition similar to the surrounding school district, about $17 \%$ of charter schools served a higher proportion of students of color, and about $14 \%$ enrolled a lower percentage of students of color (RPP International, 2000). ${ }^{7}$ However, there may be charter schools that have sig-

\footnotetext{
7 The researchers defined "not distinct" (meaning similar) if the charter school's composition was within $20 \%$ of the district average. Hypothetically speaking, this would mean that an essentially homogenous charter school (say, 95\% White) located within a district having one-fourth minority enrollment would be considered "not distinct".
} 
nificantly different racial and ethnic populations than traditional public schools in the same area. The most elaborate state study of racial and ethnic enrollments was conducted in Arizona, which is an atypical charter school state in several ways. The Arizona study found that a substantial number of charter schools differed from their neighboring public schools, often because they had a significantly higher proportion of White students (Cobb \& Glass, 1999).

In terms of family income, charter schools nationally served a proportion of students eligible for federal free or reduced-price lunch programs similar to district-run public schools (RPP International, 2000). In some states, however, the proportion of lowincome students enrolled in charter schools was higher than the state average, while in other states the proportion was lower.

\section{Do Charter Schools Have Equitable Admissions Practices?}

Despite early concerns, there has been little or no evidence that charter schools are pulling the most successful students from the districtrun public schools (Fuller, 2000). Most states require charter schools to be open to all students and, if charter schools accept federal Public Charter School Program funds, they must accept students based on a lottery. Still, one California study concluded that charter schools "have more power than most public schools to shape their school communities" (Wells, 1998, p. 42). For example, charter schools can use targeted recruitment, mandatory parental involvement policies, and applicants' prior records (in some states) to avoid students they do not want to enroll. Other researchers have identified similar practices (see Cobb \& Glass, 1999).

\section{Do Charter Schools Enroll the Same Proportion of Students with Disabilities as District-run Public Schools?}

A recent national study suggests that a slightly smaller percentage of students with disabilities are enrolled in charter schools $(8 \%)$ than in public schools (11\%) (RPP International, 2000). Reasons for the disparity may include charter staff reluctance to admit students whose special needs they feel they cannot meet as well as parental reluctance to enroll children with significant disabilities (Fiore, Harwell, Blackorby, \& Finnigan, 2000).
However, one study found that "students with and without disabilities receive more individualized attention at the charter school than they did at their previous school" (Fiore et al., 2000, p. 41). There is also a tension between charter schools, with their emphasis on autonomy, and the "highly regulated nature of special education;" this tension may ultimately place important limits on charter school autonomy (Rhim \& McLaughlin, 2001, p. 373).

\section{Impact}

\section{Are Charter Schools Producing Gains in Student Achievement?}

This question is difficult to answer for several reasons. Charter schools differ considerably from state to state and district to district. Charter schools tend to be too new to have established track records. They have enrollments that are unstable or quite different from public schools. And, charter schools use a variety of standardized tests or alternative assessments that often vary from year to year. In addition, the quality of research varies considerably: some studies have exercised considerable effort to use appropriate controls and make suitable comparisons (see Miron \& Nelson, 2000; Solmon, Paark, \& Garcia, 2001), while others have been less cautious. It is thus not surprising that a recent review of student achievement in charter schools by RAND researchers found that, "...evidence on the academic effectiveness of charter schools is mixed" (Gill et al., 2001, p. 95). Similarly, the most comprehensive analysis of findings on charter school achievement concluded that "the charter impact on student achievement appears to be mixed or very slightly positive" (Miron \& Nelson, 2001).

One study found that charter schools in Michigan had significantly lower state test scores and lower two- and three-year test score gains than their host districts (Horn \& Miron, 1999). Some Michigan charter schools, however, had higher scores, at least at some grade levels. A second Michigan study used an Annual Yearly Progress analysis to show that more charter schools $(83 \%$ in math and $63 \%$ in reading) than comparison schools (58\% in math and $46 \%$ in reading) achieved their improvement targets in 1997-1998 (Public Sector Consultants and MAXIMUS, 1999). 
Charter schools had particular success in moving students from low to moderate achievement groups.

A recent study of charter schools in Pennsylvania found mixed achievement outcomes. The average charter school scores on the state assessment were 140 points lower than the average scores for district-run public schools, although the difference was smaller when charters were compared to their home districts (Miron \& Nelson, 2000). But, several Pennsylvania charter schools outperformed district-operated schools and their home districts. Mixed results were found in other states, including Illinois and Massachusetts (Illinois State Board of Education, 1999; Massachusetts Department of Education, 1997).

Still, several studies suggest that some charter schools are seeing gains in student achievement. A Colorado study of 51 charter schools found that they outperformed the state, their authorizing districts, and public schools serving students from similar socioeconomic backgrounds (Fitzgerald, 2000). Achievement data from Los Angeles show that charter schools that began with high average scores maintained high scores over time, and schools that began with very low average scores generally showed improvement comparable to, and sometimes stronger than, comparison schools (WestEd \& University of Southern California, 1998). An Arizona study that incorporates relatively complex statistical analyses of longitudinal achievement test scores concluded that, in reading, charter school students enrolled for two and three years "have an advantage over" students in district-run public schools for the same time periods (Solmon et al., 2001, p. 4).

Charter schools in Washington, DC, on the other hand, were outperformed by the district-operated public schools on the Stanford9 Achievement Test. Researchers cautioned against premature conclusions, however, because limited research has been conducted on the public school test results (Henig et al., 1999). The 1997-1998 Texas study of the first 19 open-enrollment charter schools (most of which were established to serve students at risk of dropping out) reported that charter school students performed at lower levels than students enrolled in district-run public schools (Texas Education Agency, 1999). This study also noted that three charter schools outperformed the state average, with one achieving state "recognized" status (Texas Education Agency, 1999).

No conclusive data indicate that charter schools overall are failing their students, and some charters are showing positive achievement results. Additional research on student achievement is needed to look beyond aggregate test scores and to focus on why students in some charter schools show greater achievement gains than in others. As Gill and his colleagues explain, "...these charter school evaluations...have been black boxes, making no attempt to explain the reasons for any measured effects on student achievement. Getting inside the black box is especially important, because charter schools (like private schools) are by their nature diverse" (Gill et al., 2001, p. 96).

\section{Are Charter Schools Causing Changes in the Public School System?}

Advocates expected that charter schools would create a ripple effect where districts would "...change and improve their systems in response to the appearance of charter laws and charter schools" (RPP International, 2001, p. 5). The ripple effect would result from the need to compete with charter schools for students, and from the ability to borrow educational ideas from local charter schools. Research findings about such systemic effects have been mixed. Several studies found little evidence of district change in response to competition. Rofes, for example, found that most of the districts he studied had "gone about business-as-usual" (Rofes, 1998, p. 11) (see also Arsen et al., 1999; Texas Education Agency, 2000; Wells, 1998). On the other hand, RPP International (2001) found evidence of districts responding to charter schools in every district studied. Common responses to the charter schools, according to the Rofes and RPP studies, included increased marketing and public relations efforts, and new programs or "theme schools" similar to those offered by the charter schools. The differences in the study findings seem largely related to how much change qualified as a "significant" district change.

Rofes (1998) reported that district personnel seldom saw or used charter schools as laboratories for educational innovations; he argued that, for this to happen, charter 
schools would have to be generating new knowledge and districts would have to be open to using that knowledge in their schools. The new programs reported by RPP probably would not qualify as innovative under the Rofes definition. Two studies identified a different way that charter schools were "encouraging" district change: some district administrators used charter schools as a mechanism for promoting educational reform within their districts (RPP International, 2001; Teske, Schneider, Buckley, \& Clark, 2000).

Overall, it appears that many, but not all, districts with multiple charter schools were responding to the changing landscape of public education offerings in some manner. Many of these responses, however, were only potential, "intermediate" steps toward improving the quality of conventional public schools. In his attempt to assess the impact of charter schools on student achievement in neighboring district-run public schools, Bettinger did not find evidence suggesting that scores were increasing as a result of competition. He did find, however, some preliminary evidence suggesting that district-run public schools near charter schools may experience decreasing scores. But, as Bettinger notes, "The short-run effects may differ substantially from the long-run equilibrium with charter schools" (Bettinger, 1999, p. 21).

\section{Policy Implications}

Some questions about charter schools can be answered far more clearly than others. For example, evidence is strong that parents and students remaining in charter schools are satisfied with their experiences, and that charter schools are more autonomous than districtoperated public schools (although the level of autonomy varies considerably). But research is only beginning to illuminate some of the most important questions - about innovation, accountability, equity, and student achievement.

Innovation. Charter schools, although not always innovative in the sense of offering something new, do look different than district-run public schools in certain ways, including management and organization. It is unclear, however, if and when such differences translate into changed classroom practice or student achievement. For policymak- ers, a focus on school quality, rather than school innovation, may be more likely to yield the educational results envisioned by charter school advocates. Future research needs to focus on where improved instruction and achievement are occurring, and identifying the institutional and political structures that promote these improvements.

Accountability. The market side of the accountability equation for charter schools is operating as envisioned by advocates far more consistently and predictably than the government side. Policymakers should carefully deliberate about the appropriate government role in charter school accountability, and then reconsider current statutes and funding levels for authorizing agencies in light of that role and the apparently rare closure of schools for insufficient student achievement.

Equity. Equity issues are critical, particularly if charter schools are to serve the public interest as well as the private preferences of parents and students. Policymakers should carefully monitor admissions and recruitment practices, the potential for increased segregation, and provision of special education services.

Outcomes. Overall, available information on student achievement outcomes suggests a wait-and-see approach. More research is needed to determine, over time, why some schools perform far better than others. Any real long-term and sustained influences on the broader system are likely to emerge very slowly. Some districts are making important adaptations, but these have not reached core district operations.

Charter schools nationally have created considerable excitement and, at times, an understandable level of tension in public education. As charter schools continue to expand, continued research is needed to shed light on how this reform can advance the overall goals of improving education. 


\section{Policy Briefs}

\section{References}

Arsen, D., Plank, D., \& Sykes, G. (1999). School choice policies in Michigan: The rules matter. East Lansing, MI: Center on School Choice and Educational Change, Michigan State University.

Ascher, C., Jacobowitz, R., McBride, Y., \& Wamba, N. (2000). Reflections from New York City's charter schools and charter authorizers. New York: Institute for Education and Social Policy, New York University.

Bettinger, E. (1999). The effect of charter schools on charter students and public schools (Occasional Paper No. 4). New York: National Center for the Study of Privatization in Education, Teachers College, Columbia University.

Bomotti, S., Ginsberg, R., \& Cobb, B. (1999). Teachers in charter schools and traditional schools: A comparative study. Education Policy Analysis Archives, 7(22), http:// epaa.asu.edu/epaa/v7n22.html.

Bulkley, K. (1999). Charter school authorizers: A new governance mechanism? Educational Policy, 13(5), 674-697.

Bulkley, K. (2001). Educational performance and charter school authorizers: The accountability bind. Education Policy Analysis Archives, 9(37), http://epaa.asu.edu/epaa/ v9n37.html.

Center for Applied Research and Educational Improvement. (1998). Minnesota charter schools evaluation. Minneapolis: Author, University of Minnesota.

Center for Education Reform. (2000). Charter schools today: Changing the face of American education. Washington, DC: Author.

Clayton Foundation. (1999). 1998 Colorado charter schools evaluation study. Denver: Colorado Department of Education.

Cobb, C. D., \& Glass, G. V. (1999). Ethnic segregation in Arizona charter schools. Education Policy Analysis Archives, 7(1), http://epaa.asu.edu/epaa/v7n1/.

Finn, C. E., Manno, B. V., \& Vanourek, G. (2000). Charter schools in action: Renewing public education. Princeton, NJ: Princeton University Press.

Fiore, T., Harwell, L. M., Blackorby, J., \& Finnigan, K. S. (2000). Charter schools and students with disabilities: A national study. Washington, DC: Office of Educational Research and Improvement, U.S. Department of Education.
Fitzgerald, J. (2000). 1998-1999 Colorado charter schools evaluation study. Denver: Colorado Department of Education.

Fuller, B. (2000). The public square, big or small? Charter schools in political context. In B. Fuller (Ed.), Inside charter schools: The paradox of radical decentralization. Cambridge, MA: Harvard University Press.

Gill, B. P., Timpane, P. M., Ross, K. E., \& Brewer, D. J. (2001). Rhetoric versus reality: What we know and what we need to know about vouchers and charter schools. Santa Monica, CA: RAND.

Hassel, B. C. (1999). The charter school challenge: Avoiding the pitfalls, fulfilling the promise. Washington, DC: The Brookings Institution.

Henig, J. R., Moser, M., Holyoke, T. T., \& Lacireno-Paquet, N. (1999). Making a choice, making a difference? An evaluation of charter schools in the District of Columbia. Washington, DC: Center for Washington Area Studies, George Washington University.

Hill, P., Lake, R., Celio, M. B., Campell, C., Herdman, P., \& Bulkley, K. (2001). A study of charter school accountability. Seattle: Center on Reinventing Public Education, University of Washington.

Horn, J., \& Miron, G. (1998). First annual report of the evaluation of the charter schools and the charter school initiative in the state of Connecticut. Kalamazoo, MI: The Evaluation Center, Western Michigan University.

Horn, J., \& Miron, G. (1999). Evaluation of the Michigan Public School Academy initiative. Kalamazoo, MI: The Evaluation Center, Western Michigan University.

Illinois State Board of Education. (1999). Illinois charter school annual report 1998-1999. Springfield, IL: Author.

Kolderie, T. (1990). Beyond choice to new public schools: Withdrawing the exclusive franchise in public education (8). Washington, DC: Progressive Policy Institute.

Kolderie, T. (1998, February). What does it mean to ask: Is 'Charter Schools' working? http://www.charterfriends.org/working.html.

Koppich, J., Holmes, P., \& Plecki, M. L. (1998). New roles, new rules? The professional work 
lives of charter school teachers. Washington, DC: Center for the Advancement of Public Education, National Education Association.

Lake, R. J., \& Millot, M. D. (1998). Accountability for charter schools: A comparative assessment of charter school laws. Seattle: Center on Reinventing Public Education.

Massachusetts Department of Education. (1997). 1997 test results from Massachusetts charter schools. Boston: Author.

Mintrom, M. (2000). Leveraging local innovation: The case of Michigan's charter schools. East Lansing, MI: Michigan State University.

Miron, G., \& Nelson, C. (2000). Autonomy in exchange for accountability: An initial study of Pennsylvania charter schools. Kalamazoo, MI: The Evaluation Center, Western Michigan University.

Miron, G., \& Nelson, C. (2001). Student academic achievement in charter schools: What we know and why we know so little. New York: National Center for the Study of Privatization in Education.

Mulholland, L. A. (1999). Arizona charter school progress evaluation. Tempe, AZ: Morrison Institute for Public Policy, Arizona State University.

Nathan, J. (1996). Charter schools: Creating hope and opportunity for American education. San Francisco: Jossey-Bass.

Public Sector Consultants and MAXIMUS. (1999). Michigan's charter school initiative: From theory to practice. Lansing, MI: Author.

Rhim, L., \& McLaughlin, M. (2001). Special education in American charter schools: State level policy, practices, and tensions. Cambridge Journal of Education, 31(3), 373-383.

Rofes, E. (1998). How are school districts responding to charter school laws and charter schools? Berkeley, CA: Policy Analysis for California Education.

Rose, L., \& Gallup, A. (2000). The 32nd annual Phi Delta Kappa/Gallup Poll. Phi Delta Kappan, 82(1), 41-58.

Rosenblum Brigham Associates. (1998). Innovation and Massachusetts charter schools. Boston: Rosenblum Brigham Associates.

RPP International. (1999). The state of charter schools, third year report: National study of charter schools. Washington, DC: Office of
Educational Research and Improvement, U.S. Department of Education.

RPP International. (2000). The state of charter schools: 2000. Washington, DC: Office of Educational Research and Improvement, U.S. Department of Education.

RPP International. (2001). Challenge and opportunity: The impact of charter schools on school districts. Washington, DC: Office of Educational Research and Improvement, U.S. Department of Education.

Solmon, L., Paark, K., \& Garcia, D. (2001). Does charter school attendance improve test scores? The Arizona results. Phoenix, AZ: The Center for Market-based Education, Goldwater Institute.

SRI International. (1997). Evaluation of charter school effectiveness. Menlo Park, CA: Author.

SRI International. (2000). Evaluation of the public charter schools program: Year one evaluation report. Washington, DC: Author.

Teske, P., Schneider, M., Buckley, J., \& Clark, S. (2000). Does charter school competition improve traditional public schools? (Civic Report 10). New York: Center for Civic Education at the Manhattan Institute.

Texas Education Agency. (1999). Texas openenrollment charter schools: Second year evaluation 1997-1998. Austin, TX: Author.

Texas Education Agency. (2000). Texas charter schools: Third year evaluation. Austin, TX: Author.

Wells, A. S. (1998). Beyond the rhetoric of charter school reform: A study of ten California school districts. Los Angeles: UCLA Charter School Study.

WestEd \& University of Southern California. (1998). The findings and implications of increased flexibility and accountability: An evaluation of charter schools in Los Angeles Unified School District. San Francisco: WestEd.

Wohlstetter, P., \& Griffin, N. (1998). Creating and sustaining learning communities: Early lessons from charter schools (Occasional Paper No. OP-03). Philadelphia: Consortium for Policy Research in Education, University of Pennsylvania.

Wohlstetter, P., Wenning, R., \& Briggs, K. L. (1995). Charter schools in the United States: The question of autonomy. Educational Poli$c y, 9(4), 331-358$. 


\section{About the Authors}

Katrina Bulkley is an Assistant Professor of Educational Policy at Rutgers University. Her work focuses on issues of school reform, particularly in the area of charter schools and school choice, with a focus on issues of state policy and accountability. Currently, she is working on a project funded by CPRE that examines educational management organizations that operate charter schools and the different ways in which companies and schools negotiate their relationships.

Jennifer Fisler is a Research Associate at the Center for Education Policy Analysis at Rutgers University, and has been involved with survey research and analysis in her work at Rutgers. She recently published an article based on survey research of undergraduate women in the sciences and has spent the last four years conducting a study using surveys and interviews to look at the professional development of teachers.

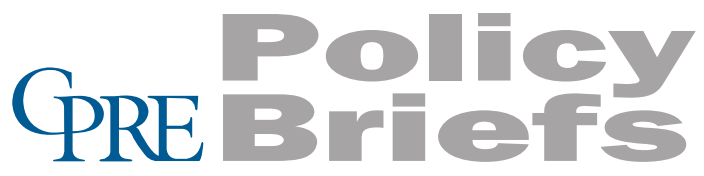

Graduate School of Education University of Pennsylvania 3440 Market Street, Suite 560

Philadelphia, PA 19104-3325

\section{About CPRE}

The Consortium for Policy Research in Education (CPRE) studies alternative approaches to education reform in order to determine how state and local policies can promote student learning. Currently, CPRE's work is focusing on accountability policies, efforts to build capacity at various levels within the education system, methods of allocating resources and compensating teachers, governance changes like charters and mayoral takeovers, finance, student and teacher standards, and student incentives. The results of this research are shared with policymakers, educators, and other interested individuals and organizations in order to promote improvements in policy design and implementation.

CPRE unites five of the nation's leading research institutions to improve elementary and secondary education through research on policy, finance, school reform, and school governance. Members of CPRE are the University of Pennsylvania, Harvard University, Stanford University, the University of Michigan, and the University of Wisconsin-Madison.

CPRE Policy Briefs are published by CPRE. To learn more about CPRE research or publications, please call 215-573-0700 or access CPRE publications at www.cpre.org; www.wcer.wisc.edu/cpre/; or www.sii.soe.umich.edu. 